\title{
American Journal of
}

\section{Health, Medicine and Nursing Practice}

(AJHMN)

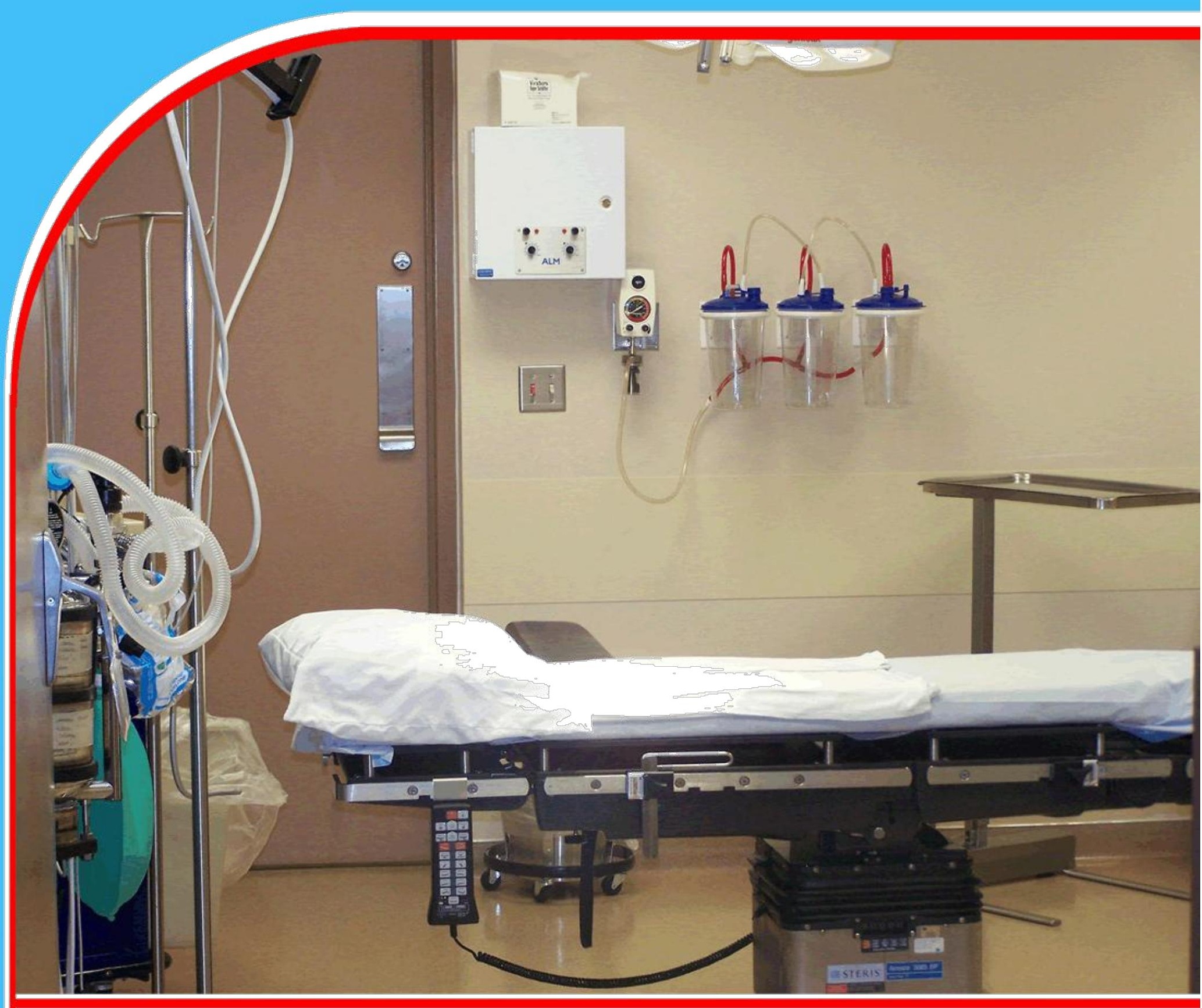

FACTORS AFFECTING NURSES' CAREER DEVELOPMENT AND ITS RELATION TO TURNOVER INTENTION

Nahed Shawkat Abo Elmagd Ebtsam Ahmed Mohamed

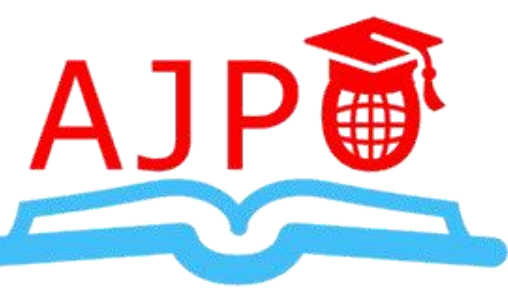




\title{
FACTORS AFFECTING NURSES' CAREER DEVELOPMENT AND ITS RELATION TO TURNOVER INTENTION
}

\author{
${ }^{1 *}$ Nahed Shawkat Abo Elmagd, ${ }^{2}$ Ebtsam Ahmed Mohamed \\ ${ }^{1}$ Assistant professor of Nursing Administration, Faculty of Nursing, Assiut \\ University, Egypt \\ ${ }^{2}$ Lecturer of Nursing Administration, Faculty of Nursing, Minia University, Egypt \\ *Corresponding Author's Email: nahedaboelmagd@yahoo.com.
}

\begin{abstract}
Purpose: The aim of the study was to identify factors affecting nurses' career development and its relation to turnover intention.

Methodology: Correlation comparative research design was done to fulfill the aim of this study. The study was conducted at Assiut university Hospitals and Minia university Hospitals. A representative sample 50\% from staff nurses at Assiut university Hospitals and Minia university Hospitals ( $\mathrm{n}=938$ ). Two tools was used for collecting data for this study, career Development Questionnaire and Modified Anticipated Turnover Scale (ATS).

Results: Affirmed that the majority of staff nurses at the Assiut university hospitals had the highest percentage regarding factors affecting career development, and had the lowest percentage regarding turnover intention than the staff nurses at Minia university hospital.

Conclusion: There were negative correlations between factors affecting nurses' career development and turnover intention among Assiut staff nurses. While, there were positive correlations between factors affecting nurses' career development and turnover intention among Minia staff nurse.

Recommendation: Administrative authority should provide support and resources, inservices training programs; opportunities to upgrade career development; and develop effective strategies to improve the staff nurses satisfaction and reduce their intention to leave.
\end{abstract}

Keywords: Nurse, Career development, Turnover intention 


\section{Introduction}

In Egypt, the system of health care is facing diverse challenges in which the health of individuals should be maintained and ensured. The quality and the delivery of health care effectiveness have been affected by the roles of nurse; in which those nurses are the largest portion of hospital health care team, so they should continuous developing their career. Also, in the $20^{\text {th }}$ century; reinforcing and developing the hospital staff nurses career development could be the most challenge confront the human resource. This arouse health care organizations and nursing educators to collaborate with staff nurses to fosters their career development activities which in turn will help nurses to provide high and effective quality care ${ }^{(1)}$.

Moreover, the ability to be more flexible, leader, creative, clinically competent, knowledge expert, as well as caregiver are the most skills required to be acquired by nurses. These skills are fundamental to nurses in order to enable them be in good position to control their careers ${ }^{(2)}$. In addition, a profession first years creates the employees career framework and affects their professional development in long term. A significant aspect for healthcare organizations and nursing profession is to appraise how nurses adopt their occupations, and be familiar with their career transitions. Thus, organizations of healthcare are required to support the nurses' working environments where nurses learning are valued, fostered, and empowered ${ }^{(3)}$.

Career Development Institute (CDI) $\mathbf{( 2 0 1 7 )}^{(4)}$ define the career development as enduring and distinctive process for each person by which they can manage their learning, work, and move forward to enable them share effectively in their community. Career development is crucial issue for each person welling personally and economically, and is important to social mobility.

Mckay, (2018) ${ }^{(5)}$ explored that the work environment had many different factors have that affect on the career development of nurses' and their participation in the activities of career development. The first factors are the personal factors as the behavior of persons, their empowerment, their satisfaction, and the practice of career development for nurses. The second factors are related to job such as supervisory support and autonomy. And finally are the factors that related to organization, such as the support of management, the plans of career development, and persistent professional developments policies.

Collins et al,(2000) ${ }^{(6)}$ explained that lifelong learning activities and developing the career in nursing can enhance the job satisfaction and decrease the job turnover. Moreover, practicing the career development for nurses is paramount in order to become more adjustable to their new job requirements. The nurses need to assess their own strengths and combining them with current career chances. They are required to grow proactive position in regard to their career ambition, so that they should promote a higher level of personal initiative ${ }^{(7)}$.

Nurse turnover can be defined as the employees 'dismissal of one specific health organization and hired to another; while turnover can be defined as the leaving of the nursing profession. In addition, in many studies, nurse turnover was recognized as the transfer of nurses from one particular department to another department at the same 
organization ${ }^{(8)}$.For many years; turnover intention has a decisive issue for management, and it considered as a major matter for all organizations today's. Turnover intention is identified as premeditation awareness to search in other organization for another alternative $^{(9)}$.

There are many factors that have a major and decisive role to frame the employee turnover; which can be wages, job performance, growth of the career, service conditions, work environment, style of supervisor, job satisfaction, employee commitment, support of manager, organizational culture, and policies that support human resource. Turnover of employee is the results from number of pressures and attractive factors that can be done during the relationship of employment ${ }^{(10)}$. Shortage of nurses' staff and the high turnover of them considered to be a pivotal challenge to health care organization. It manifested that recruitment of nursing staff and their retention are significant issues; and rate of turnover, that provide a pure reference of retention stiffness and solidity, are considerable all over the world ${ }^{(11)}$.

Moreover, there are various factors which implicit high rates of turnover among nurses. These factors include insufficiency of career development, poor advocacy from supervisors with shortage of autonomy in making the decision, pauper communication and connection within the organization, low self-esteem, ambiguity of role, low income, and the exposition to injuries whether it is physically or psychologically ${ }^{(12-14)}$.

Turnover is not unexpected incident, but it is a process that happened by series phases. It begins firstly with conflict phase between employees or within the employee and ending with feeling with negative emotions about job. So, the good management had a crucial role to tamper at the early phases of $i^{(15)}$. Therefore, the role of organizations for developing the career is to foster competitive features by embracing and raising the prominence from their human capital. It was revealed from literature evidence that, when employees are armed well with the sufficient knowledge, skills, and abilities; they can manage their career; so they become more secured about their career and this progress their satisfaction. Also, the employee satisfaction can enhance the commitment of employees and their intention to stay employed in the $\operatorname{organization}^{(16)}$.

\section{The significance of the study}

Nowadays career development becomes very important issue; this is due to the attentions for work life quality and planning for personal life to raise their educational level requirements. Also, nursing turnover is a serious trend that had an effect on the health care organizations performance and profitability in which the organization needed to have highly practice, and fully involved nursing staff to supply the patient with effective level of care. The researchers introducing this study to identify the factors affecting nurses' career development and its relation to turnover intention because it is vital to nursing practice 


\section{Aim of the Study}

The aim of the current study was to identify factors affecting nurses' career development and its relation to turnover intention

\section{Research Questions}

- What are the factors affecting nurses' career development and turnover intention?

- Is there a relation between factors affecting nurses' career development and turnover intention?

\section{Subjects and Methods}

Research Design:

Correlation comparative research design was done to fulfill the aim of this study

\section{Setting:}

The study was conducted at three hospitals of Assiut University Hospitals and three hospitals of Minia University Hospitals. The hospitals names were: Main hospital; Pediatric hospital; and Gynecology and Obstetric hospital.

\section{Subjects}

Subjects of the present study included a representative sample 50\% from staff

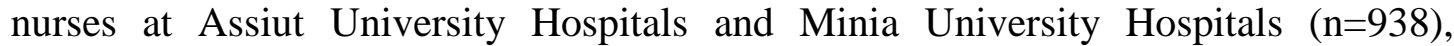
classified as follows:

\begin{tabular}{lcccc}
\multicolumn{1}{c}{ Hospitals } & \multicolumn{2}{c}{ Assiut University Hospitals } & \multicolumn{2}{c|}{ Minia University Hospitals } \\
& No study staff & Total of staff & No study staff & Total of staff \\
- Main hospital & $\mathbf{5 0 0}$ & 1000 & $\mathbf{1 0 4}$ & 208 \\
- Pediatric hospital & $\mathbf{1 6 0}$ & 320 & $\mathbf{2 5}$ & 49 \\
- Gynecology and & $\mathbf{1 2 0}$ & 240 & $\mathbf{2 9}$ & 57 \\
$\begin{array}{c}\text { Obstetric hospital } \\
\text { Total }\end{array}$ & $\mathbf{7 8 0}$ & 1560 & $\mathbf{1 5 8}$ & 314 \\
\hline
\end{tabular}

\section{Data Collection Tools}

Two tools were used to collect data as follow:

Tool (1): Career Development Questionnaire (CDQ) classified into two parts:

Part one; Personal data sheet: It was used to collect data about the personal data characteristics of the study participants. It included items related to age, gender, qualification, years of experience, hospitals name, and marital status.

Part two; The Career Development Questionnaire (CDQ): this part was developed by Ismaiel, (2013) ${ }^{(3)}$. It used to collect the data with regard to the factors which could affect nurses' career development. The questionnaire included three factors measured by (88 items): personal factors, job factors and organizational factors with a total of 8 dimensions. It was distributed as:

- Personal factors which included (50 items); divided to 4 dimensions as personal behaviors (13items); empowerment (12 items); satisfaction (13 items); and nurses' career development practice (12items). 
- Job-related factors which included (27 items) encompasses of 2 dimensions as: autonomy (14 items); and supervisory support (13 items)

- The organizational factors which included (11 item) containing 2 dimensions as: management support (6 items) and career developmental plans (5 items).

Responses for all dimensions factors were measured on 5-point likert scale ranging from "1" strongly disagree to "5" strongly agree; except satisfaction factor ranging from "1" strongly dissatisfied to "5" strongly satisfied, and nurses' career development practice factor measured yes(1) or no(0). Scores were planned by summing and averaging the items in each factor.

Scoring system of the tool was as follows:

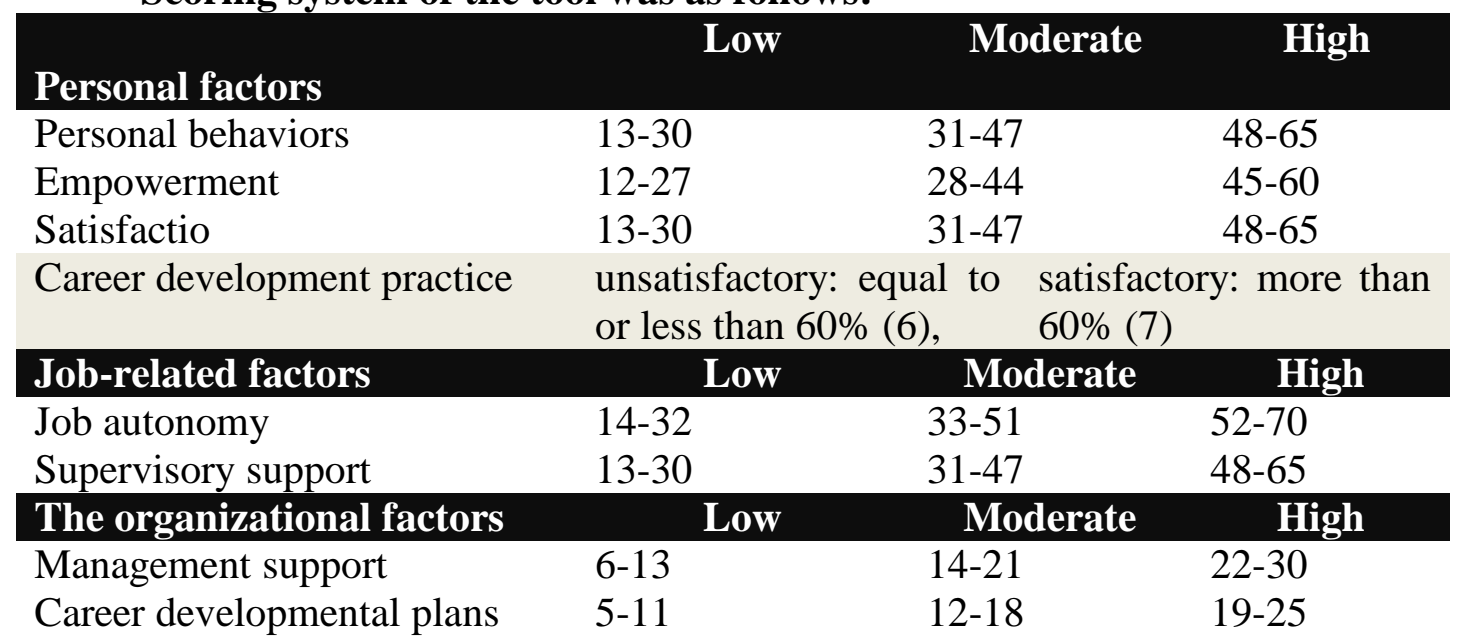

\section{Tool (2): Modified Anticipated Turnover Scale (ATS)}

This scale was developed by Hinshaw and Atwood,(1984) ${ }^{(17)}$ to measure turnover intention among nurses. The self-reported ATS instrument contained (12 items); measured by 5 points likert - format as $(1=$ strongly disagree, $2=$ disagree, $3=$ uncertain, $4=$ agree, $5=$ strongly agree). The tool divided into 2 parts as follows: -

- Negative statements that contained (6 items) and, which measured the intention of staff nurses to stay in the present work settings.

- Positive statements that contained (6 items) and, which measured the intention of staff nurses to leave the present work settings.

The scoring system was calculated by summing all the items in the scale divided by number of items in each scale. The higher score indicated there is a greater intent to leave the present setting. Regarding the scoring system of intention to leave and intention to stay: it was as following, total turnover intention score: $60 \%$, intention to stay: equal to or less than $60 \%$ (36), intention to leave: more than $60 \%$ (37).

\section{Validity of the study tools}

The content validity of the current study tools was established by a panel of five experts in the field of Nursing Administration; from Faculty of Nursing, Assiut and Minia Universities. Each expert panel was asked to assess the tools for its content, wording, length, coverage clarity, format and its overall appearance. No modification done from the jury panel. 


\section{Reliability of the study tools}

Reliability test was estimated using the Cronbach's Alpha Coefficient for the study tools. Cronbach's Alpha Coefficient was used to measure the internal consistency of the items composing to each dimension factor in the tool. The values of reliability for career development tool were; part (I) personal factors was (0.754), for part (II) job factors was (0.881)and for part (III) organizational factors was (0.880). The modified anticipated turnover scale reliability was: for part (I)intention to leave(0.795) and for part (II)intention to stay( 0.821$)$.

\section{Pilot study}

The pilot study was carried out on (10\%) of the participants(94 nurses) to ensure the clarity and applicability of the tools items, and to determine the time required to complete the tools. The results showed that the time spent in filling the tools was ranged between 20-30 min. Based on the pilot study analysis no modifications were done in the tools. So, number of the pilot study was included in the total number of the study sample.

\section{Procedure}

- Official permission was obtained from the director of Assiut university hospitals, and Minia university hospitals after explaining the nature of the work.

- Tools were translated into Arabic.

- The researchers explained the aim, nature and significance of the study for every participant to get better cooperation during the implementation phase of the research

- Oral consent was obtained from each participant in the study after explaining the purpose of the study

- During data collection the researchers handled the questionnaire sheets individually to the participant staff nurses then explained the questionnaire sheets to them asking for their participation.

- The researchers waited until the participants completed the sheets and were ready to answer any question

- Data was collected for a period nearly two months from beginning of June to the end of July 2019.

\section{Ethical Consideration}

Verbal explanation of the nature and the aim of the current study were given to the staff nurses who included in this study. Staff nurses were given the right to refuse or to participate, and they were promised that their information and data would be confidentially; and will be utilized and used for the study purpose only.

\section{Statistical design}

Data entry and statistical analysis were done using computer software, the statistical package for social studies (SPSS), version 21. Suitable descriptive statistics were used such as frequencies, and percentages for qualitative variables, means, and standards deviations for quantitative variables. Correlation coefficient (r) test was used to estimate the closeness association between variables. For all the tests used, statistical significance was considered at $\mathrm{p}-$-value $<0.05$. 
American Journal of Health, Medicine and Nursing Practice

ISSN 2520-4017 (Online)

Vol.5, Issue 1 No.3 pp 25-42, 2020

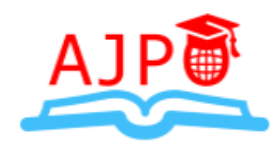

www.ajpojournals.org

\section{Results}

Table (1): Distribution of the staff nurse's personal data characteristics $(n=938)$

\begin{tabular}{|c|c|c|c|c|}
\hline \multirow[t]{2}{*}{ Characteristics } & \multicolumn{2}{|c|}{$\begin{array}{c}\text { Assiut University } \\
\text { Hospitals } \\
\text { N=(780) }\end{array}$} & \multicolumn{2}{|c|}{$\begin{array}{c}\text { Minia University } \\
\text { Hospitals } \\
\mathrm{N}=(\mathbf{1 5 8})\end{array}$} \\
\hline & $(\mathbf{N})$ & $(\%)$ & $(\mathbf{N})$ & $(\%)$ \\
\hline \multicolumn{5}{|l|}{ Age } \\
\hline 20-30 year & 264 & 33.8 & 57 & 36.1 \\
\hline 31-41 year & 440 & $\begin{array}{c}56.4 \\
\end{array}$ & 84 & 53.2 \\
\hline 42-52 year & 76 & 9.7 & 17 & 10.8 \\
\hline$\overline{\text { Mean }+ \text { SD }}$ & \multicolumn{2}{|c|}{$34.45 \pm 6.52$} & \multicolumn{2}{|c|}{$34.56 \pm 6.68$} \\
\hline \multicolumn{5}{|l|}{ Gender } \\
\hline Male & 98 & 12.6 & 17 & 10.8 \\
\hline Female & 682 & 87.4 & 141 & 89.2 \\
\hline \multicolumn{5}{|l|}{ Qualification } \\
\hline Bachelor & - & - & - & - \\
\hline Technical & 412 & $\begin{array}{l}52.8 \\
\end{array}$ & 86 & 54.4 \\
\hline Diploma & 368 & 47.2 & 72 & 45.6 \\
\hline \multicolumn{5}{|l|}{ Years of experience } \\
\hline $1-10 y r s$ & 266 & 34.1 & 57 & 36.1 \\
\hline $11-21 \mathrm{yrs}$ & 321 & 41.2 & 60 & 38 \\
\hline$<22 \mathrm{yrs}$ & 193 & 24.7 & 41 & 25.9 \\
\hline \multicolumn{5}{|l|}{ Hospitals name } \\
\hline Main & 500 & 64.1 & 104 & 65.8 \\
\hline Pediatric & 160 & 20.5 & 25 & 15.8 \\
\hline Obstetric & 120 & 15.4 & 29 & 18.4 \\
\hline \multicolumn{5}{|l|}{ Marital status } \\
\hline Single & 146 & 18.7 & 31 & 19.6 \\
\hline Married & 634 & 81.3 & 127 & 80.4 \\
\hline
\end{tabular}

Table (1) shows that more than half $(56.4 \%$ and $53.2 \%$ respectively) of the study sample in Assiut university hospitals and Minia university hospitals are between $31-41$ years; the majority $(87.4 \%$ and $89.2 \%)$ of them in both universities are females. Besides, more than half (52.8\% and 54.4\%) of them have technical degree followed by (47.2\% and $45.6 \%$ ) have diploma degree in both universities. Also, (41.2\% and 38\%) of study sample in both universities have 11-21 years of experience, in addition $(64.1 \%$ 
American Journal of Health, Medicine and Nursing Practice ISSN 2520-4017 (Online)

Vol.5, Issue 1 No.3 pp 25-42, 2020

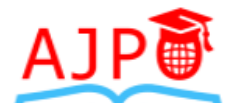

www.ajpojournals.org

and $65.8 \%$ ) of them in both universities working at Main hospitals. Finally as regards to marital status the majority $(81.3 \%$ and $80.4 \%)$ of the them in both universities are married.

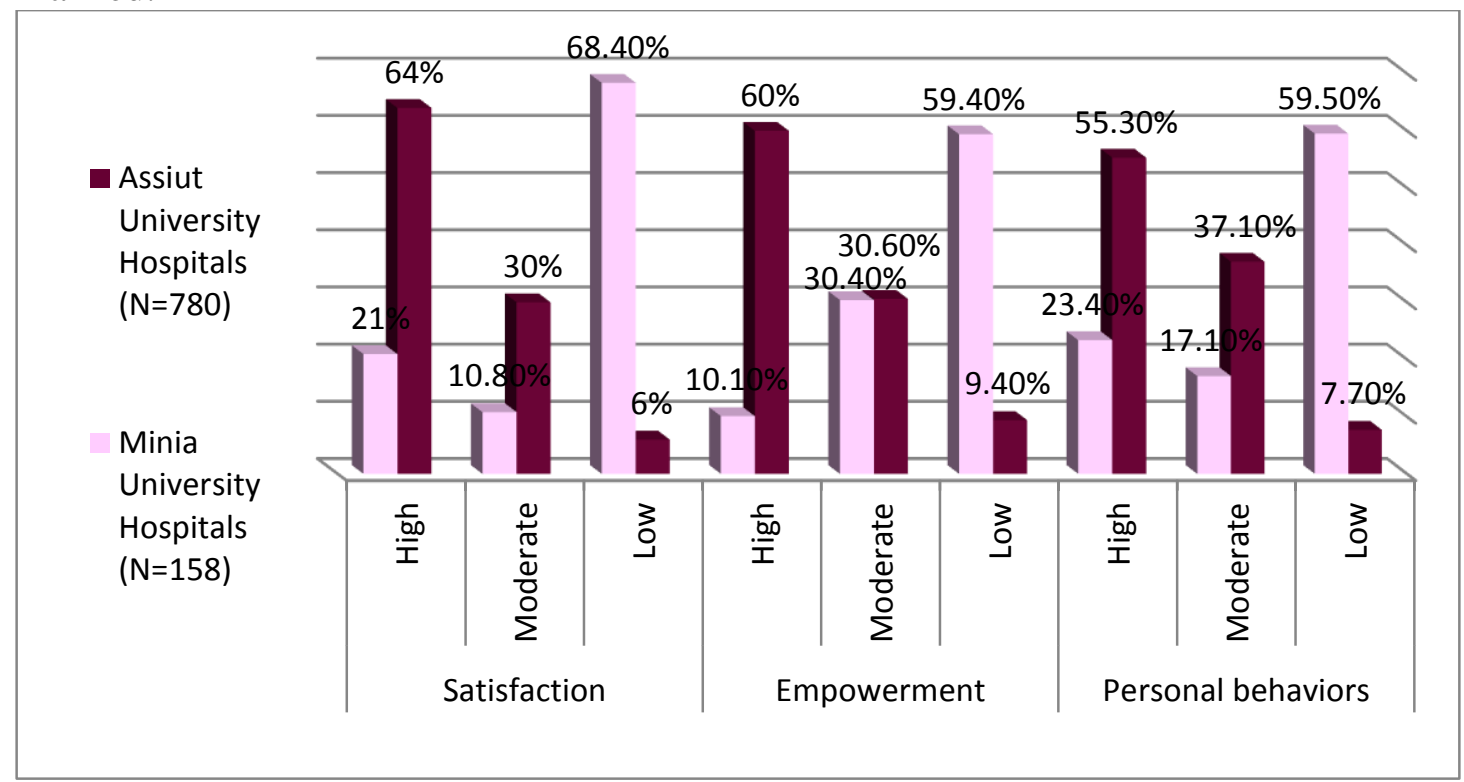

Figure (1) Distribution of nurses' responses regarding personal behaviors, empowerment, and satisfaction dimensions of the personal factors $(\mathrm{N}=938)$

\section{Career development practices}

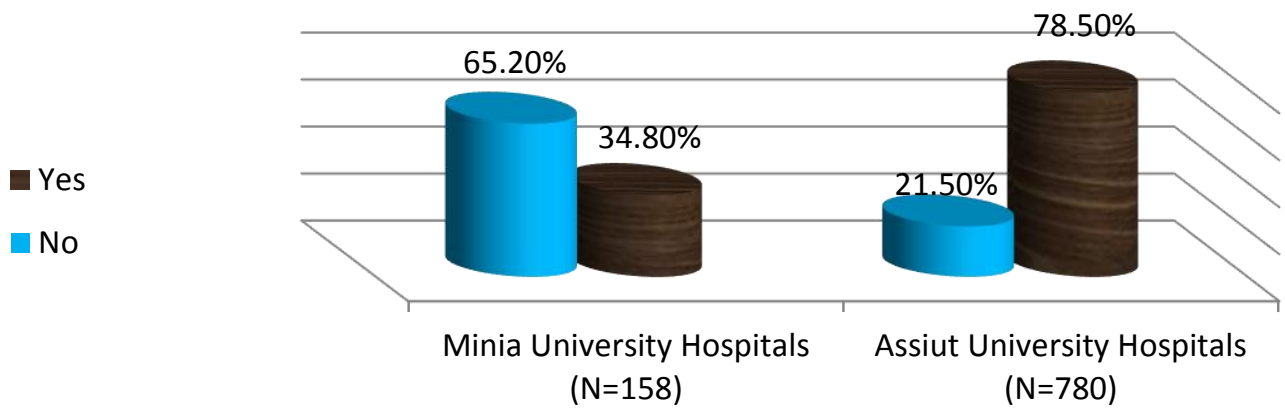

Figure (2) Distribution of nurses' responses regarding career development dimension of the personal factors $(\mathrm{N}=938)$

Figures (1, and 2) display that, nearly two third percent of Assiut university hospitals staff nurses exhibit "high "responses toward personal factor dimensions which include "personal behaviors, empowerment, satisfaction "by $(55.3 \%, 60 \%$, and $64 \%$ respectively). Moreover, $78.5 \%$ of the nurses are responses "yes" with mean score for career development practices dimension. While, at Minia university hospitals the staff nurses exhibit "low "responses toward personal factor dimensions which include "personal behaviors, empowerment, satisfaction "by $(59.5 \%, 59.4 \%$, and $68.4 \%$ 
respectively). Moreover, (65.2\%) of the nurses have high responses for "No" regarding career development practices dimension.

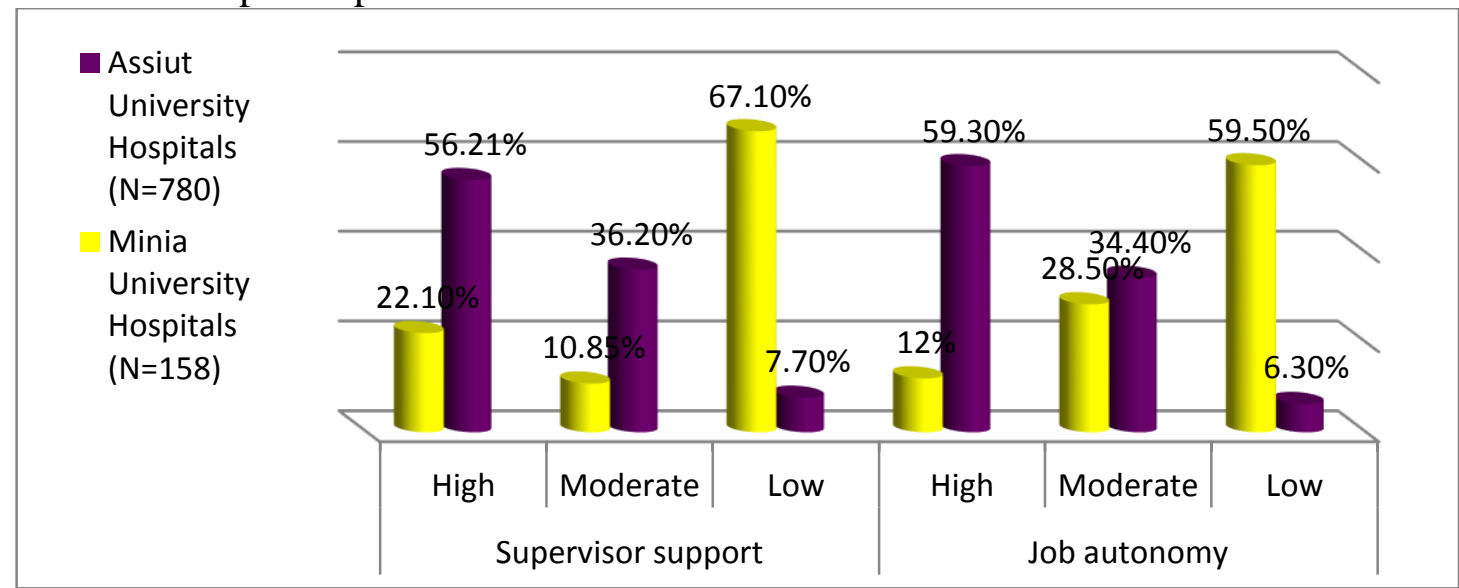

Figure (3) Distribution of nurses' responses level about the job factors (N=938)

Figure (3) displays that, more than fifty percent of Assiut university hospitals staff nurses exhibit "high "responses toward job factors dimensions which include "job autonomy and supervisor support "by (59.4\% and56.2\% respectively). While, staff nurses of Minia university hospitals exhibit low "responses" (59.5\% and 67.1\%) for job autonomy and supervisor support respectively.

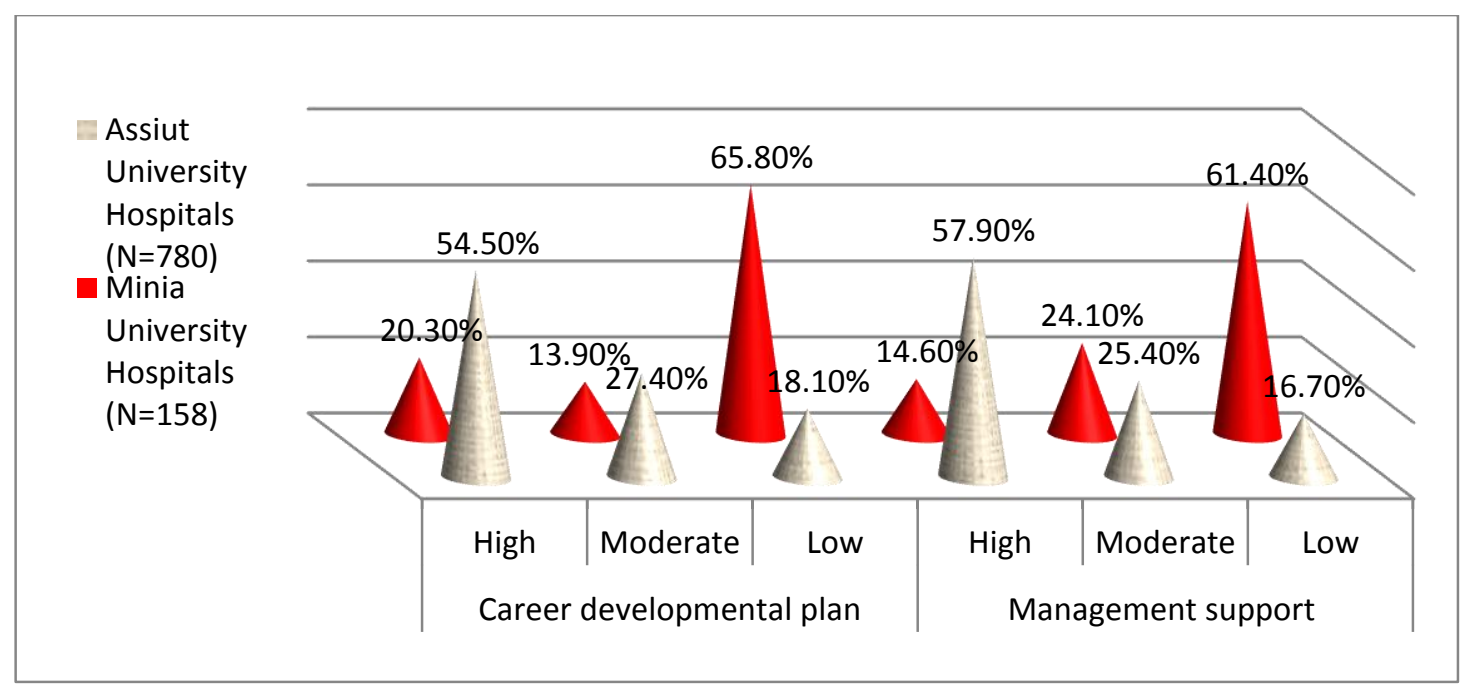

Figure (4) Distribution of nurses' responses level about the organizational factors $\underline{(\mathrm{N}=938)}$

Figure (4) shows that, more than fifty percent of Assiut university hospitals staff nurses exhibit "high responses" toward organizational factors dimensions which include "management support and career development plan $(57.9 \%$ and $54.5 \%$ respectively). However, staff nurses of Minia university hospitals exhibit "low responses" (61.4\% and 65.8\%) for management support and career development plan respectively. 
American Journal of Health, Medicine and Nursing Practice

ISSN 2520-4017 (Online)

Vol.5, Issue 1 No.3 pp 25-42, 2020

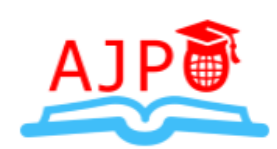

www.ajpojournals.org

Table (2) The differences between Assiut and Minia University Hospitals staff nurses regarding their mean score of the factors affecting nurses' career development among $(n=938)$

\begin{tabular}{|c|c|c|c|c|}
\hline \multirow[t]{2}{*}{ Variable } & $\begin{array}{c}\text { Assuit hospitals } \\
(\mathrm{N}=780)\end{array}$ & $\begin{array}{c}\text { Minia hospitals } \\
(\mathrm{N}=\mathbf{1 5 8})\end{array}$ & \multirow[t]{2}{*}{$\overline{\mathbf{T}}$} & \multirow[t]{2}{*}{$\overline{\mathbf{P}}$} \\
\hline & Mean \pm SD & Mean \pm SD & & \\
\hline \multicolumn{5}{|c|}{ Personal factors } \\
\hline - Personal behaviors & $44.17 \pm 8.04$ & $31.40 \pm 13.1$ & 16.1 & $0.000 * *$ \\
\hline - Empowerment & $43.40 \pm 10.7$ & $25.4 \pm 11.9$ & 18.5 & $0.000 * *$ \\
\hline - Satisfaction & $45.41 \pm 7.76$ & $29.44 \pm 12.6$ & 20.8 & $0.000 * *$ \\
\hline $\begin{array}{l}\text { - Career development } \\
\text { practices }\end{array}$ & $7.80 \pm 2.60$ & $5.05 \pm 3.33$ & 11.4 & $0.000 * *$ \\
\hline Total personal factor & $140.48+21.8$ & $91.3+28.5$ & 24.3 & $0.000 * *$ \\
\hline \multicolumn{5}{|c|}{ Job factors } \\
\hline • Job autonomy & $48.54 \pm 8.13$ & $36.8 \pm 10.2$ & 16.5 & $0.000 * *$ \\
\hline - Supervisor support & $44.24 \pm 8.13$ & $29.6 \pm 12.7$ & 18.4 & $0.000 * *$ \\
\hline Total of job factor & $92.78 \pm 11.6$ & $66.5 \pm 17.2$ & 23.6 & $0.000 * *$ \\
\hline \multicolumn{5}{|c|}{ Organizational factors } \\
\hline - Management support & $17.46 \pm 5.53$ & $15.23 \pm 5.29$ & 13.8 & $0.000 * *$ \\
\hline - Career developmental plan & $35.21 \pm 5.56$ & $37.84 \pm 5.16$ & 4.65 & $0.000 * *$ \\
\hline $\begin{array}{l}\text { Total of organizational } \\
\text { factor }\end{array}$ & $38.51 \pm 8.96$ & $29.34 \pm 7.65$ & 12.01 & $0.000 * *$ \\
\hline Total career development & $223.23 \pm 27.7$ & $150.34 \pm 34.8$ & 28.7 & $0.000 * *$ \\
\hline
\end{tabular}

Table (2) explains that there are statically significant differences between all factors affecting nurses' career development among Assiut and Minia University hospitals in which $\left(\mathrm{p}\right.$-value $\left.=0.000^{* *}\right)$. Also, the same table shows that there is statically significant difference of nurses' total career development between Assiut and Minia University hospitals in which the staff nurses of Assuit University hospital have higher mean score than staff nurses of Minia University hospital ( $p$-value $=0.000^{* *}$ ). 


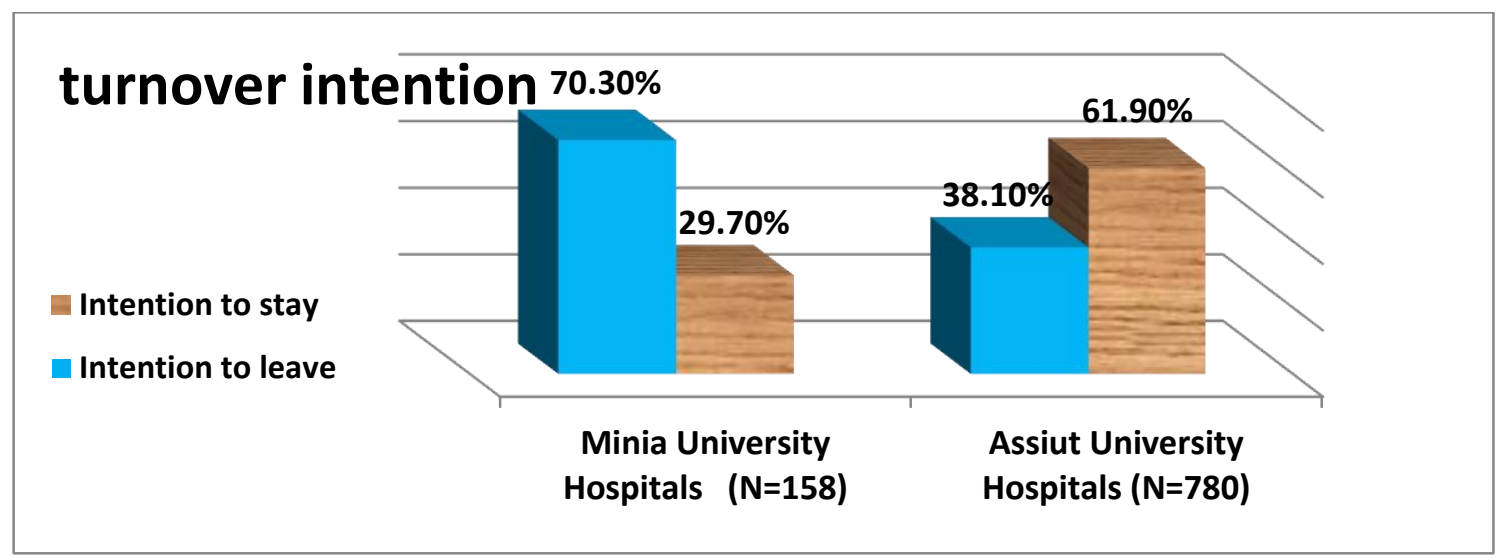

Figure (5) Distribution of nurses' responses level about the turnover intention $(\mathbf{N}=938)$

Figure (5) shows that, more than sixty percent of Assiut university hospitals staff nurses exhibit "high "responses toward intention to stay by (61.9\%); while, about seventy percent of Minia university hospitals staff nurses, exhibit "high "responses toward intention to leave by $(70.3 \%)$.

Table (3) The correlation between factors affecting nurses' career development and turnover intention among Assiut staff nurses $(\mathbf{n}=\mathbf{7 8 0})$

\begin{tabular}{|c|c|c|c|c|c|}
\hline \multicolumn{2}{|l|}{ Variable } & $\begin{array}{c}\text { Personal } \\
\text { factor }\end{array}$ & $\begin{array}{c}\text { Job } \\
\text { factor }\end{array}$ & $\begin{array}{l}\text { Organizational } \\
\text { factor }\end{array}$ & $\begin{array}{l}\text { Turnover } \\
\text { intention }\end{array}$ \\
\hline Personal factor & $\begin{array}{l}\mathbf{R} \\
\mathbf{P}\end{array}$ & $\overline{1}$ & $\begin{array}{l}.292 * * \\
.000\end{array}$ & $\begin{array}{l}.175 * * \\
.000\end{array}$ & $\begin{array}{c}.290-* * \\
.000\end{array}$ \\
\hline Job factor & $\begin{array}{l}\mathbf{R} \\
\mathbf{P}\end{array}$ & - & $\overline{1}$ & $\begin{array}{l}.230 * * \\
.000\end{array}$ & $\begin{array}{l}.380- \\
.292\end{array}$ \\
\hline Organizational factor & $\begin{array}{l}\mathbf{R} \\
\mathbf{P}\end{array}$ & 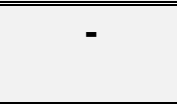 & & $\overline{11}$ & $\begin{array}{l}.470-* \\
.038\end{array}$ \\
\hline Turnover intention & $\begin{array}{l}\mathbf{R} \\
\mathbf{P}\end{array}$ & - & - & - & 1 \\
\hline
\end{tabular}

Table (3) shows that, there are statistical negative correlation between factors affecting nurses' career development and turnover intention among Assiut university hospital staff nurses. 
Table (4) The correlation between factors affecting nurses' career development and turnover intention among Minia staff nurses $(n=158)$

\begin{tabular}{|c|c|c|c|c|c|}
\hline \hline \multicolumn{2}{|c|}{ Variable } & $\begin{array}{c}\text { Personal } \\
\text { factors }\end{array}$ & $\begin{array}{c}\text { Job } \\
\text { factors }\end{array}$ & $\begin{array}{c}\text { Organizational } \\
\text { factors }\end{array}$ & $\begin{array}{c}\text { Turnover } \\
\text { intension }\end{array}$ \\
\hline Personal factor & $\mathrm{R}$ & 1 & $.160^{*}$ & .609 & .421 \\
& $\mathrm{P}$ & & .045 & .391 & .072 \\
\hline \hline Job factor & $\mathrm{R}$ & - & 1 & .119 & .590 \\
& $\mathrm{P}$ & & & .135 & .234 \\
\hline \hline Organizational factor & $\mathrm{R}$ & - & & 1 & .800 \\
& $\mathrm{P}$ & & & & .029 \\
\hline \hline Turnover intension & $\mathrm{R}$ & - & - & - & 1 \\
\hline
\end{tabular}

Table (4) shows that, there are positive correlation between factors affecting nurses' career development and turnover intention among Minia university hospital staff nurse's

\section{Discussion}

The staff nurse and their level of experience was highlighted to be an important portion of the health care system which can affect instantly the quality of provided care. Also, the shortage of nursing staff has become an increasingly imperious primacy in the new decades and has imparted a chain of challenges and trends to hospitals all over the world ${ }^{(18,19)}$. Recent studies suggested that the presence of high nurse turnover rate may resulted from the overload of the work, prolonged shift hours, difficulties work relationships, and poor chances for career advancement ${ }^{(20,21)}$.

The high rate of nurses' turnover has a major effect on the quality of patient care, and it also imparted severe economic havoc to these organizations and countries. The total cost for nursing staff low level of retention, including low productivity and high costs for hiring and training new staff, which could extended to be more than 5\% of the annual operating budget in a major medical center ${ }^{(22)}$.

Regarding to the distribution of nurse's staff members according to their personal data characteristics at Assiut university hospitals and Minia university hospitals; it was noted from the current study that more than half $(56.4 \%$ and $53.2 \%$ respectively) of the study sample in Assiut university hospitals and Minia university hospitals aged between $31-41$ years; the majority $(87.4 \%$ and $89.2 \%$ ) of them in both hospitals were females. Besides, more than half $(52.8 \%$ and $54.4 \%)$ of them had technical degree followed by $(47.2 \%$ and $45.6 \%)$ had diploma degree in both hospitals. Also (41.2\% and 38\%) of study sample in both hospitals had 11-21 years of experience, in addition (64.1\% and $65.8 \%$ ) of them in both hospitals worked at Main hospitals. Finally regards to marital status the majority $(81.3 \%$ and $80.4 \%)$ of them in both hospitals were married

As regarded to the personal factors dimensions, it was appeared that Assiut university hospitals nurse's had high level and high mean score for all dimensions 
(personal behaviors, empowerment, satisfaction, and career development) than Minia university hospital nurses' for career development. The nurses at Assiut university hospitals are more self-confident, have willingness for learning new practice and knowledge; and have the ability to evaluate their strengths and weaknesses. Moreover, nurses are more empowered and satisfied about what they do; they have mastered the necessary needed skills for their job and they are seeking for the feedback about their performance.

These results might be attributed to the Assiut staff nurses were involved in many activities and participated in different nursing committee which provide them more opportunities for developing their career, more satisfaction and confident about their job. Moreover, they are looking forward to receive guidance and acceptance from their supervisors. In the opposite line Minia staff did not accepted to learn new skills and they had not receive feedback about their performance; or motivated from their supervisors so they were not satisfy about their job.

These results are consistent with Chen et al., (2012) ${ }^{(23)}$ who indicated a positive correlation between nurses' empowerment and their career development practices. Also, Bahadoriand Fitzpatrick, (2009) ${ }^{(24)}$ study findings explored evidence that nurses are skillful, competent, masterful, and seeking performance feedback because they are involved in different activities and participated in nursing committee to develop their career.

In the same line Takase, (2010) ${ }^{(25)}$ stated that the appreciation of nurse in their work is known from their psychological response in which if they are bad in their response, this will cause stress; and this can lead nurses to feel with dissatisfaction and had poor organizational commitment. In this respect, Aytac, (2005) ${ }^{(26)}$ is consensus that in the career development individuals are responsible for determining their own weaknesses, strengths, and needs for development, and integrating them with current career opportunities.

Concerning the job factors dimension it was found that more than half of Assiut staff had high level than Minia staff as regard to the job autonomy and they were performing skills freely, accepting the consequences for their choices which reflects on their self-stem and self-respect. This result is due to that the Assiut staff nurses used to work and take decisions independently regarding the work and the patient care because the supervisor encouraging them to act as a team and providing them initial support during the work to accomplish their goal of care. In contrast the staff nurses at Minia university hospitals did not receive support during the work from their supervisors; also, the supervisors did not allow them to participate in the decision making.

This result is supported by Woods and Lynn, (2014) ${ }^{(27)}$ who concluded that support in work was positively associated with career growth. Work support from supervisors had a significant impact on their employees' career exploration, career goal, and career strategy; as well as provides benefits to overall nurses' career growth and self-fulfillment. Moreover, Restubog, et al., (2011) ${ }^{(28)}$ displayed a significant positive correlation between career development for the employee and supervisor support they have. Also, their study highlighted the crucial role that nurse leaders should master for both smoothing professional development and merging new professional uniformity into nursing. 
Moreover, the present study finding found that more than half of Assuit staff had high level than staff nurses at Minia hospitals as regard to the organizational factors dimension, it was apparent that nurses are supported from the superiors and supported from the organizational. The staff had more information about training and education opportunities inside the hospital; as well as the superiors implement innovative evaluation processes or provide constructive feedback about staff performance. In addition, there guidance or career counseling is provided.

These finding could be attributed to, nursing managers at Assiut hospitals had adequate human and material resources as much as possible, clear policy, feedback system, Also the presence of in-service education program as well as continuing education center inside those hospitals. Therefore, nurses get rewards or appropriate attention for their development, interest, innovation or personal goals. On the other hand, staff nurses at Minia hospitals suffer from; inadequate human and material resources, unclear police about the organization and the organization did not provide continuous education process.

These results are consistent with Zhang, $(\mathbf{2 0 1 3})^{(29)}$ who revealed that on the individual level, nurses with a higher level of career growth usually have a more positive working attitude and a higher level of professional skill. Therefore, at the unit level, when enhancing the nurse with the sufficient opportunities for organizational career growth can help nurses to build a better working environment, as well as improve the overall patients care. In the same line Asegid et al., (2014) ${ }^{(30)}$ concluded that the integration of work support and organizational career growth at both individual and unit level can increase the sense of achievement in nurses and lead to more job satisfaction, high quality nursing service, and decrease in turnover intention.

Finally, the results of the present study at the two hospitals " Assiut university hospitals and Minia university hospitals as regard to the factors affecting on nurses' career development and turnover intention, revealed that there was negative correlation between factors affect career development (personal, job and organizational) and job turnover at Assiut university hospitals. While , the staff nurses who working at Minia university hospitals had positive correlation between factors affect career development (personal, job and organizational) and job turnover. The interpretation of these findings may be due to that the staff nurses at Assiut university hospitals receive continuous education; supervisor supports; motivation from supervisors; encouragement to participate in decision making through using of democratic leadership style; availability of resources and the supervisors helping staff nurses to overcome the obstacles that facing them in the work; all of these can lead to staff nurses' job satisfaction and low turnover.

These results are supported by Mosadeghrad(2013) $)^{(31)}$; Budiono and Alamsyah, (2014) ${ }^{(32)}$ and Kusumaningrum \& Harsanti, (2015) ${ }^{(33)}$ who agreed on satisfaction factors affecting turnover intention of nurse. Mosadeghrad(2013) ${ }^{(31)}$ who displayed that when there is higher nurse satisfaction, there will be lower nurse willingness to leave their workplace. Also, Yin, et al., (2011) ${ }^{(34)}$; De Gieter et al., $\mathbf{( 2 0 1 1 )}^{(\mathbf{3 5})}$;Lusiati, (2013) ${ }^{(36)}$ and Yeun\&Jeon, (2015) ${ }^{(37)}$ stated that nurse turnover intention are affected by many factors such as spirituality and personal factors. 
On other hand Takase (2010) ${ }^{(25)}$ displayed that turnover intention is caused by the organization factors such as (organizational culture, organizational characteristics, and relations in the organization), occupation as (stress of work, work overload, financial reward, work environment culture, and employee opportunity to access to authority), as well as the employee factors such as (personal data, demographic, behaviors, and attitudes of employee)

In the same line Budiono and Alamsyah, (2014) ${ }^{(32)}$; Yeun \&Jeon, $\mathbf{( 2 0 1 5 )}^{(\mathbf{3 7})}$;Rubel\&Kee, (2015) ${ }^{(38)}$; and Lee et al., (2016) ${ }^{(39)}$ studies concluded that turnover intention showed significant results in organizational policy, work, interpersonal relations, and environment factor. One of the organizational policy is organizational commitment, the higher a person's commitment to the organization, the lower possibility to resign from the workplace. Also, De Gieter, (2011) ${ }^{(35)}$;Rachman, (2016) $^{(40)}$ stated that turnover intention have a relationship related to the occupational factors. Occupational factors can include work affiliates, imbalanced work-life, and too much work that lead to stress. Also, Hayes and Almalki (2011) ${ }^{(8)}$ mentioned that if there is a lot of work overload as well as there is insufficient support; this produce an emotional problems which can lead to stress; and in turn the stress will arouse turnover intention among employee.

\section{Conclusion and recommendations}

The findings of the current study affirmed that the majority of staff nurses at Assiut university hospitals had the highest percentage regarding their perception toward factors affecting their career development, and had the lowest percentage regarding turnover intention. In contrast the majority of the staff nurses at Minia university hospitals had the lowest percentage regarding their perception toward factor affecting on career development, and had the highest percentage regarding turnover intention

Also, there were a negative correlation between factors affecting nurses' career development and turnover intention among Assiut university staff nurses. While, a there were a positive correlation between factors affecting nurses' career development and turnover intention among Minia university staff nurse

In light of the conclusions of this study, it was recommended that:

- Administration support and resources should be provided through, in-services training programs; and opportunities for further education to upgrade the general awareness level of career development strategies.

- Periodically, the administrator of the hospitals should identify the cause of intentions to leave; and develop effective strategies to improve the staff nurses satisfaction and reduce the intention to leave

- Development of the rewards system and recreational service to enhance nurse's motivation.

- The organization should encourage their supervisors to use effective communication skills and support for staff nurses, which helps to reduce turnover intention. 


\section{References}

1. Bjo M, Athlin E, Johansson I. Nurses development of professional self From being a nursing student in a baccalaureate program to an experienced nurse. Journal of Clinical Nursing 2008; 17(10): 1380-91.

2. Hooley T. The Evidence Base on Lifelong Guidance: A Guide to Key Findings for Effective Policy and Practice. European Lifelong Guidance Policy Network. 2014. Available at http://www.elgpn.eu/publications/browseby-language/english/elgpn-tools-no-3.-theevidence-base-on-lifelong-guidanceextended-summary. Cited on, November, 20, 2019.

3. Ismaiel M H. Factors Affecting Nurses' Career Development Journal of American Science 2013; 9(5) available@ http://www.jofamericanscience.org.

4. Career Development Institute (2017). Definitions: Career development and related roles. Cited from https://www.google.com.eg/search. Cited on, November, 20, 2019.

5. Mckay D.R. Career Development What is it and what factors influence it? 2018. Cited from https://www.thebalancecareers.com/what-is-career-development525496. Cited on, November, 2, 2019.

6. Collins K, Jones M, McDonnell A, Read S, Jones R, Cameron A. Do new roles contribute to job satisfaction and retention of staff in nursing and professions allied to medicine? Journal of Nursing Management, 2000; 8(1): 3-12.

7. Seibert S, Kraimer M, Crant, J. What do proactive people do? A longitudinal model linking proactive personality and career success. Personnel Psychology, 2001; 54: 845-74.

8. Hayes L, Almalki A. Nurse Turnover. A literature reviews. International journal of nursing studies, 2011; 43(2): 226-37.

9. Chen MF, Lin CP \& Lien GY. Modeling job stress as a mediating role in predicting turnover intention. The Service Industries Journal, 2011; 31(8): 1743-49.

10. Jafari A. Prime and subprime factors of employee voluntary turnover in the boom phase of industry. Empirical evidence from banking sector of Pakistan. Afr. J. Bus. Manage, 2011; 5(15): 6408-14.

11. Race TK \&Skeek JS. Changing tides: improving outcomes through mentorship on all levels on nursing. Crit Care Nurs Q. 2010 Apr-Jun;33(2):163-76

12. Gardulf A, Soderstrom L.I, Oroton M. L, Eriksson L.E., Arnetz B, Nordstrom G.Why do nurses at a university hospital want to quit their jobs? J NursManag. 2005; 13(4):320-27.

13. Fochsen G1, Sjögren K, Josephson M, Lagerström M. Factors contributing to the decision to leave nursing care: A study among Swedish nursing personnel. J NursManag. 2005; 13(4):338-44.

14. Chiu Y, Chung R, Wu C, Ho C. Effects of job demands control, and social support on hospital clinical nurses' intention to turnover. Journal of Applied Nursing Research, 2009; www.sciencedirect.Com.

15. Branham L. The 7 hidden reasons employees leave, American Management Association 2005. Cited from https://www.leadershipbeyondlimits.com/wp- 
content/uploads/2013/06/WhyPeopleLeave-Branham.pdf. Cited on, November, 25, 2019.

16. Nitardy C M. The Relationship between Career Development and Intent to Stay in a High Turnover Industry, Early Childhood Education and Care. Doctroal dissertation, Faculty of the Graduate School, University of Minnesota, 2008.

17. Hinshaw AS, Atwood JR. Testing a theoretical model for job satisfaction and anticipated turnover of nursing staff. Nursing Research, 1984; 34-6.

18. Lin H. Revisiting the relationship between nurse staffing and quality of care in nursing homes: An instrumental variables approach. Journal of health economics, 2014; 37, 13-24.

19. Manzano-García G, Ayala-Calvo J. C. An overview of nursing in Europe: a SWOT analysis. Nursing inquiry, 2014; 21(4), 358-67.

20. Gurková E, Soósová MS, Haroková S, Žiaková K, Šerfelová R, Zamboriová M. Job satisfaction and leaving intentions of Slovak and Czech nurses. International nursing review, 2013; 60(1): 112-21.

21. Shiao J, Lee Y, Ho JJ, Hu PY, Guo L. Factors predicting nurses' consideration of leaving job (Also to be considered for mini-symposium: Early detection and management of workers under stress). Occup Environ Med, 2014; 71(Suppl 1), A94-A95.

22. Waldman JD, Kelly F, Aurora S, Smith, HL. The shocking cost of turnover in health care. Health care management review, 2004; 29(1), 2-7.

23. Chen SH, Fu CM, Li RH, Lou JH, Yu HY. Relationships among social support, professional empowerment, and nursing career development of male nurses: A cross-sectional analysis. Western journal of nursing research, 2012; 34(7): 86282.

24. Bahadori A, Fitzpatrick JJ. Level of autonomy of primary care nurse practitioners. Journal of the American Academy of Nurse Practitioners, 2009; 21(9): 513-9.

25. Takase M. A concept analysis of turnover intention: Implications for nursing management. Collegian, 2010; 17(1), 3-12.

26. Aytac S. Çalışma Yaşamında Kariyer Yönetimi, Planlaması, Gelişimive Sorunları [Career management, planning, development and problems in work life] (2005).

27. Woods AM, Lynn SK. One physical educator's career cycle: Strong start, great run, approaching finish. Res Q Exerc Sport., 2014; 85(1): 68-80.

28. Restubog SLD, Bordia P, Bordia S. Investigating the role of psychological contract breach on career success: Convergent evidence from two longitudinal studies. J VOCAT BEHAV, 2011; 79(2), 428-37.

29. Zhang H. Male nurses professional attitudes and job satisfaction and job burnout of correlation research. [MSN dissertation]. Henan University; (Article in Chinese), 2013.

30. Asegid A, Belachew T, Yimam E. Factors influencing job satisfaction and anticipated turnover among nurses in Sidama zone public health facilities, South Ethiopia. Nursing research and practice, 2014.https://www.hindawi.com/journals/nrp/2014/909768/ 
31. Mosadeghrad AM. Occupational Stress and Turnover intention: Implications for Nursing Management. International Journal of Health Policy and Management(IJHPM), 2013, 1(2: 169-76.

32. Budiono S, Alamsyah A. Pengaruh Spiritualitas di Tempat Kerjaterhadap Turnover intention Perawatmelalui Komitmen Organisasional di Rumah Sakit Islam Unisma Malang. Jurnal Aplikasi Managemen, 2014; 12(4)1-9.

33. Kusumaningrum D, Harsanti I. Kontribusi Kepuasan Kerja Terhadap Intensi Turnover Pada Perawat Instalasi RuangInap. Prosiding PESAT (Psikologi, Ekonomi, Sastra, Arsitektur \&TeknikSipil, 2015; 6.

34. Yin W, Fox T, Stokes DP, Adam C. Work-related stress and intention to quit in newly graduated nurses. Nurse Education Today, 2012; 32: 669-74.

35. De Gieter S, Hofmans J, Pepermans R. Revisiting the impact of job satisfaction and organizational commitment on nurse turnover intention: An individual differences analysis. International journal of nursing studies, 2011; 48(12): 1562-9.

36. Lusiati A, Supriyanto, A, Stefanus. Dampak Faktor Individu, Faktor Pekerjaandan Faktor Organisasi Pada Kepuasan Kerjadan Intensi Turnover Perawat. Journal Administration Kesehatan Indonesia, 2013; 1(2).

37. Yeun EJ, Jeon M. Relationship between Nursing Professionalism, internal marketing, and turnover intention among hospital nurses. Indian Journal of Science and Technology, 2015; 8(25):1-6.

38. Rubel MR, Kee DM. Perceived fairness of performance appraisal, promotion opportunity and nurse's turnover intention: The role of organizational commitment. Asian Social Science, 2015; 11(9):183.

39. Lee KE, Kim JH, Jong-Kim M. Influence of Perceived Organizational Justice on Empowerment, Organizational Commitment and Turnover intention in the Hospital Nurses. Indian Journal of Science and Technology, 2016; 9(20):1-8.

40. Rachman L, Dewanto A. Pengaruh Employee Engagement terhadapKepuasanKerjadan Turnover intention Perawat (Studipada Rumah Sakit Wava Husada Kepanjen Malang). Jurnal Aplikasi Managemen, 2016; 14(2):29-38. 